\title{
Analysis of Heavy Metal Content in Soil Fertilised with Fresh and Granulated Digestate
}

\author{
Anna Bartkowiak*, Milena Piątek \\ Instytut Technologiczno-Przyrodniczy w Falentach, Poznań Branch, Poznań, Poland
}

Received: 11 December 2019

Accepted: 30 January 2020

\begin{abstract}
Our study analysed the content of selected heavy metals ( $\mathrm{Fe}, \mathrm{Zn}, \mathrm{Mn}, \mathrm{Pb}, \mathrm{Cd}, \mathrm{Ni}$ and $\mathrm{Cu}$ ) in soils fertilised with mineral fertilisers (NPK and CaNPK), and fresh and granulated digestate. The content of the elements was compared with non-fertilised treatments ( 0 and control treatment). The maximum permitted limits were found not to have been exceeded in any of the treatments. The study demonstrated that the digestates under analysis were safe for use as fertilisers. The contents of $\mathrm{Zn}, \mathrm{Cu}$, and $\mathrm{Mn}$ after fertilisation with fresh digestate were found to be statistically significantly lower than in the control treatments. Following the application of the granulated materials, smaller quantities of $\mathrm{Cu}, \mathrm{Fe}$ and $\mathrm{Cd}$ were noted.
\end{abstract}

Keywords: fresh digestate, digestate granules, mineral fertilization, heavy metals

\section{Introduction}

Soil is one of the basic non-renewable resources of the natural environment, which is why it should be protected. It contains all the nutrients necessary for the growth of plants, which in turn are a valuable source of food for animals and humans. One of the main threats to soils, particularly those used for farming purposes, is the presence of heavy metals. Sources of heavy metals in agricultural areas include fertilisers and waste, as well as plant protection products [1-5].

Heavy metals are found in all soil types, but if their natural concentrations are exceeded, they become a significant threat. An excess of heavy metals in the soil inhibits the development of microorganisms, thus interfering with the processes involved in the turnover of organic matter. It also causes the accumulation

*e-mail: a.bartkowiak@itp.edu.pl of toxic elements in plant tissues, which adversely affect the reproduction of plants, and thus reduce their nutritional value. In humans and animals, heavy metals may produce mutagenic, carcinogenic or embryotoxic effects [6-9].

The maximum permitted content of substances causing risk in agricultural areas, including heavy metals, is defined in the Regulation of the Minister of the Environment of 1 September 2016 on the method of conducting assessment of soil surface contamination [10]. Annex 1 to the Regulation contains, among other things, a listing of the maximum permitted contents of heavy metals in the soil (Table 1). The ranges for different substances are defined depending on soil depth, with a division into soil groups based on their type of use, soil subgroups (soil properties), and water permeability of soil and ground.

According to Ociepa-Kubicka and Ociepa [9], heavy metals, depending on their influence on living organisms, can be classified into those showing 
Table 1. Permissible content of selected heavy metals in soil.

\begin{tabular}{|c|c|}
\hline Element & Permissible content \\
\hline Arsenic $(\mathrm{As})$ & $10-50$ \\
\hline Chromium $(\mathrm{Cr})$ & $150-500$ \\
\hline Tin $(\mathrm{Sn})$ & $10-50$ \\
\hline Zinc $(\mathrm{Zn})$ & $300-1000$ \\
\hline Cadmium $(\mathrm{Cd})$ & $2-5$ \\
\hline Cobalt $(\mathrm{Co})$ & $20-60$ \\
\hline Copper $(\mathrm{Cu})$ & $100-300$ \\
\hline Molybdenum $(\mathrm{Mo})$ & $10-50$ \\
\hline Nickel $(\mathrm{Ni})$ & $100-300$ \\
\hline Lead $(\mathrm{Pb})$ & $100-500$ \\
\hline Mercury $(\mathrm{Hg})$ & $2-5$ \\
\hline
\end{tabular}

Source: Piątek, Bartkowiak [2019a]

beneficial effects and those producing an adverse impact.

Beneficial effects occur at doses not exceeding maximum permitted limits, and promote the normal progress of metabolic processes and healthy functioning of living organisms. This group of elements includes Fe, $\mathrm{Mn}, \mathrm{Cu}, \mathrm{Zn}$, and Mo. However, excessive accumulation of these elements in the soil is harmful, particularly to plants [6, 11-16].

- Iron is one of the key microelements present in the soil, but excessive amounts of iron can be toxic to plants, reducing their ability to take up other nutrients such as phosphorus. A surplus of iron is manifested through the inhibition of plant growth, browning of roots, and excessive colouration and drying of leaves. The content of Fe in soils is linked both to the type of parent rocks and soil formation processes. Soils usually contain between 0.5 and $5 \%$ of the element. Plants usually take up iron from the soil in the form of $\mathrm{Fe}^{2+}$. Most $\mathrm{Fe}$ is accumulated in leaves, followed by shoots. The smallest amounts are detected in plant roots.

- Zinc - the mean content of $\mathrm{Zn}$ in soils across the world is approximately $64 \mathrm{ppm}$, while the average content in all mineral soils in Poland varies from 33 $\mathrm{ppm}$ in sands to $80 \mathrm{ppm}$ in heavy clay soils. Soluble zinc-organic complexes, which are found primarily in municipal sewage sludge, are very mobile in the soil, and easily accessible to plants. Therefore, soil contamination due to excessive amounts of zinc can be an important environmental problem. A surplus of zinc in plants leads to the chlorosis of young leaves, and has an adverse effect on plant and root growth.

- Copper plays a significant role in the physiological processes of plants. The main sources of soil contamination caused by copper compounds include fertilisers and sprays, agricultural or municipal waste, and industrial dusts. $\mathrm{Cu}$ is an element that It is involved with in a number of processes such as photosynthesis, respiration, carbohydrate distribution, protein and vitamin $\mathrm{C}$ synthesis, as well as $\mathrm{N}$ reduction and fixation. Excessive amounts of $\mathrm{Cu}$ lead to severe abnormalities, including tissue damage and elongation of root cells, changes in membrane permeability, leakage of ions (e.g., K) and substances dissolved from roots, peroxidation of chloroplast membrane lipids, and inhibition of the photosynthetic electron transport. Signs of excess copper in plants include iron chlorosis, i.e., yellowing of the tissue between the veins of young leaves. Other characteristic features include dark green leaf colour with a slight bluish hue, as well as shortened and thickened stems. In humans, copper overload is very rare, but the excess accumulates primarily in the liver, brain, and the cornea of the eye, and can ultimately result in damage to these organs.

- Manganese has a significant impact on a range of soil properties, mainly contributing to $\mathrm{pH}$ increase. Even though Mn can be concentrated in various soil horizons (predominantly those rich in $\mathrm{Fe}$ oxides or hydroxides), the element usually accumulates in the upper soil profiles as a result of its fixation by organic matter. All manganese compounds play a very important role as soil components, especially in plant nutrition and control of the behaviour of several other trace elements. Mn compounds are known for their rapid oxidation and reduction under varying soil conditions.

- Nickel is one of the components of urease, and its content is known to be the highest in ultramafic rocks (1400 to $2000 \mathrm{ppm}$ ). In addition, it is responsible for the activation of arginine and certain peptidases, and it is involved in the transport of nitrogen to the above-ground plant parts. The distribution of nickel in soil profiles is linked to organic matter or amorphous oxides and clay fractions (depending on soil type). The level of $\mathrm{Ni}$ in the soil is strongly correlated with the content of this element in parent rocks. However, the concentration of $\mathrm{Ni}$ in surface soils also reflects on soil formation processes and the presence of contaminants. Recently, nickel has become a major contaminant because of urbanisation and industrialisation processes - most notably the production of sewage sludge and municipal waste. Other potentially important sources of $\mathrm{Ni}$ include some of the phosphorus fertilisers. Anthropogenic sources of this element, particularly related to industrial activities, have led to a significant increase in Ni content in soils. Excessive amounts of nickel in plants disrupt photosynthesis, and interfere with the ionic equilibrium through their negative impact on the metabolism of nutrients (including iron). Nickel can also be toxic to humans by causing allergies, and at high doses it may affect the cardiovascular system and kidneys. 
Adverse effects are caused by metals which, even in trace amounts, pose a major threat to living organisms, e.g., $\mathrm{As}, \mathrm{Hg}, \mathrm{Pb}$, and $\mathrm{Cd}$. These elements are particularly dangerous to people, and may lead to acute poisoning and cancer, among other effects. The consequences of heavy metal exposure to the human body are long-lasting. Numerous studies have shown that elements such as lead and cadmium are particularly dangerous, and have a negative impact both on plant yield and human health. The natural cadmium content in soils ranges from 0.2 to $1.05 \mathrm{mg} / \mathrm{kg} \mathrm{DM}$. The element is very mobile, active and easily absorbed by plants because of the readily available form of the $\mathrm{Cd}^{2+}$ ion. Environmental concerns are growing, since $\mathrm{Cd}$ ranks among the most toxic metals, adversely affecting the biological activity of soil, plant metabolism, human health, and the animal kingdom. An excess of cadmium in plants is manifested by the twisting of leaves and the appearance of brown spots on the leaf surface. Another toxic element is lead. Its natural content in the soil is closely linked to the composition of the rock substrate. Lead is characterised by the lowest mobility of all heavy metals. The highest $\mathrm{Pb}$ content in the soil is noted in highly industrialised regions. Lead can enter the body via two routes: the food chain and inhalation of soil dust. It is a very dangerous metal that has been shown to exert a negative effect on people, animals and plants. An excess of lead reduces crop yields and causes dark green or red patches on the leaf surface. The soil lead content exceeding $500 \mathrm{mg} / \mathrm{kg}$ is toxic. Characteristically, this heavy metal accumulates in the human body, as it does not break down in the environment. Doses of approximately 20 to $50 \mathrm{~g}$ are known to be lethal [13, 17-19].

In their studies of the content of total and bioavailable forms of selected elements $(\mathrm{Cd}, \mathrm{Cr}, \mathrm{Ni}, \mathrm{Cu}$, $\mathrm{Pb}, \mathrm{Zn}$ and $\mathrm{Mn}$ ) in agricultural soils, Koncewicz-Baran and Gondek [20] showed that the greatest proportion of the soils under study naturally contained $\mathrm{Ni}, \mathrm{Cu}$ and $\mathrm{Pb}$. Other soils were found to have an elevated content of $\mathrm{Cd}$ and $\mathrm{Zn}$. It has been repeatedly demonstrated that mineral fertilisers contain heavy metals that lead to soil contamination. The greatest contamination with heavy metals is in phosphorus fertilizers, and less in calcium, potassium and nitrogen fertilizers. The accumulation of these elements in the fertiliser material depends mostly on the technology used, and the material from which fertilisers are produced.

In sustainable agriculture production, one method for reducing the risk due to excessive amounts of heavy metals in the soil involves the use of digestate for fertilization. Digestate is a valuable organic fertiliser enriching the soil with easily absorbed nutrients. It can be used both in its liquid form, as a solid (granulated material), and as compost [3, 22-29].

Digestate utilisation or application as a fertiliser is regulated by Polish law. Annex 1 to the Act of 14 December 2012 on Waste [30] lists three methods of digestate utilisation:
- Process R3 - composting and other biological transformation processes.

- Process R1 - use as a fuel or other means to generate energy.

- Process R10 - direct land treatment resulting in benefit to agriculture or ecological improvement.

The chemical composition of digestate is similar to that of natural fertilisers: manure, liquid manure and slurry. Used for fertilisation purposes, digestate can cover the mineral requirements of plants while preventing the negative effects of overfertilisation with mineral fertilisers. Furthermore, it shows a narrow carbon-nitrogen $(\mathrm{C}: \mathrm{N})$ ratio, which entails more rapid degradation in the soil $[23,31]$.

Digestate can be composted and processed into granulated material obtained in the process of dehydration followed by granulation and drying of dry matter. Consequently, it is characterised by the highest dry matter content, and high content of organic dry matter (Table 2). Fresh digestate pulp is processed into granulated material using waste heat generated by CHP units in biogas plants $[32,33]$.

According to Kuppera et al. [34], products such as compost and digestate obtained from organic residues can also be a source of soil contamination. The authors analysed solid composts and liquid digested products to determine their content of heavy metals $(\mathrm{Cd}, \mathrm{Co}, \mathrm{Cr}$, $\mathrm{Cu}, \mathrm{Ni}, \mathrm{Pb}$, and $\mathrm{Zn}$ ), taking into account factors that might have affected their concentrations, including the type of processing, composition, origin, particle size and content of contaminants in the starting materials, season of material collection or degree of organic matter degradation. They found that the mean content of heavy metals in the composts was $60 \%$ or less of the maximum permitted thresholds. The content of $\mathrm{Cd}, \mathrm{Co}, \mathrm{Pb}$ and $\mathrm{Zn}$ was $20 \%$ to $50 \%$ lower in solid digested products, but the values determined for $\mathrm{Cr}, \mathrm{Cu}$ and $\mathrm{Ni}$ were similar. For the majority of the elements, liquid digested products showed mean concentrations that were approximately twice as high as the values measured in the compost. However, statistical analyses failed to identify any clear links between the evaluated factors and the heavy metal content.

Table 2. Dry matter and organic dry matter content of digestate [\%].

\begin{tabular}{|c|c|c|}
\hline Product & $\begin{array}{c}\text { Dry matter } \\
\text { content }\end{array}$ & $\begin{array}{c}\text { Organic dry } \\
\text { matter content }\end{array}$ \\
\hline Digestate & 5 & 79 \\
\hline Solid fraction & 20 & 87 \\
\hline Liquid fraction & 30 & 76 \\
\hline Digestate compost & 33 & 78 \\
\hline Digestate granules & 95 & 79 \\
\hline
\end{tabular}

Source: own study based on Kowalczyk-Juśko, Szymańska., 2015 
Table 3. Nitrogen, phosphorus and potassium content in soil used in the experiment and $\mathrm{pH}$.

\begin{tabular}{|c|c|c|c|c|}
\hline \multirow{2}{*}{ Treatment } & \multirow{2}{*}{$\mathrm{pH}$} & \multicolumn{3}{|c|}{ Content in soil } \\
\cline { 3 - 5 } & 4,65 & $\mathrm{~N}$ & $\begin{array}{c}\mathrm{P} \\
\mathrm{mg} \cdot \mathrm{kg}^{-1}\end{array}$ & 41,50 \\
\hline 0 & 4,62 & 0,84 & 42,79 & 67,77 \\
\hline NPK & 6,03 & 1,04 & 49,21 & 60,94 \\
\hline CaNPK & 1,11 & 60,87 & $\mathrm{~kg}^{-1}$ \\
\hline
\end{tabular}

Source: own study

In another study, Pilarska et al. [31] assessed the content of heavy metals $(\mathrm{Cd}, \mathrm{Cu}, \mathrm{Ni}, \mathrm{Pb}, \mathrm{Zn}, \mathrm{Hg})$ in digested pulp and composts produced from it. Based on their analyses of organic materials, the authors showed no significant differences in the content of the elements, except for the pulp and compost obtained from sewage sludge, where the content of $\mathrm{Zn}$ was found to be about twice as high as in the other fertilisers.

In light of the above considerations, the aim of this study was to analyse the content of selected heavy metals (Fe, $\mathrm{Zn}, \mathrm{Mn}, \mathrm{Pb}, \mathrm{Cd}, \mathrm{Ni}$ and $\mathrm{Cu}$ ) in soils fertilised with mineral fertilisers, digestate, and digestate-based granulated materials. The content of the elements was compared to non-fertilised treatments.

\section{Experimental}

Our study was conducted in the experimental station of the Faculty of Agriculture and Biology, Warsaw University of Life Sciences (SGGW), in Skierniewice in 2016-2017. Digestates were produced in two digesters with a volume of $147 \mathrm{dm}^{3}$ each. In the first digester, the substrates were maize silage and distillers' solubles. The resulting digestate was designated as MPF1. In the second digester, a mixture containing maize silage and pig slurry was used. The digestate thus produced was designated as MPF2. In both cases of methane fermentation, the proportions were adjusted so that the dry matter content of the substrate was approximately $12 \%$. The resulting digestates were dried to achieve a dry matter content of approximately $85 \%$, and then subjected to granulation to obtain granulated materials: GCF1 (from digestate MPF1) and GCF2 (from digestate MPF2).

Soil for the pot experiment was collected from longterm fertilisation experiments conducted in the Faculty Experimental Station of SGGW. It was fortified with inorganic nutrients as follows:

- 0 - non-fertilised and non-lime-treated soil.

- NPK - soil fertilised with nitrogen, phosphorus and potassium.

- CaNPK - lime-treated soil fertilised with nitrogen, phosphorus and potassium.

The physicochemical properties of the soil samples used in the experiments are listed in Table 3.
Nutrients sources were:

- $\mathrm{N}$ as ammonium nitrate at a dose of $90 \mathrm{~kg} \mathrm{~N} \cdot \mathrm{ha}^{-1}$.

- $\mathrm{P}$ as triple superphosphate $-26 \mathrm{~kg} \mathrm{P} \cdot \mathrm{ha}^{-1}$.

- $\mathrm{K}$ as highly concentrated potassium salt $91 \mathrm{~kg} \mathrm{~K} \cdot \mathrm{ha}^{-1}$.

- $\mathrm{Mg}$ and $\mathrm{Ca}$ as magnesium and calcium fertiliser in the amount of $1.14 \mathrm{~kg} \mathrm{Mg}+\mathrm{Ca}^{-h^{-1}}$.

The experiment was conducted in an SGGW greenhouse. The plant tested was winter oilseed rape, Sherlock variety, treated with Cruiser 70 WS herbicide. The digestate products investigated, namely MPF1, MPF2, GCF1, GCF2, were applied at doses equivalent to $170 \mathrm{~kg} \mathrm{~N} \cdot \mathrm{ha}^{-1}$. Controls consisted of corresponding non-fertilized digestate products.

Soil samples were collected from each pot and sieved through a $2-\mathrm{mm}$ mesh screen. The contents of $\mathrm{Fe}, \mathrm{Zn}, \mathrm{Mn}, \mathrm{Pb}, \mathrm{Cd}$, $\mathrm{Ni}$ and $\mathrm{Cu}$ in air-dried soil samples were determined by the ASA method in $1 \mathrm{~mol} \cdot \mathrm{dm}^{-3} \mathrm{HCl}$ extract. The results obtained were subjected to oneway ANOVA variance analysis, and the separation into homogeneous groups was performed with Tukey's test at a significance level of $p<0.05$. Statistical analyses were conducted with the Statistica 10.0 package.

\section{Results and Discussion}

The study results are presented in Tables 4-10.

The study showed significantly lower differences $(\mathrm{p}<0.05)$ between the content of $\mathrm{Zn}$ in control (nonfertilised) versus CaNPK (fertilised and limetreated) soil that received the digestate product MPF1 (Table 4). In this treatment, CaNPK caused about a 20\%

Table 4. Content of zinc ( $\mathrm{Zn})$ in 0 , NPK and CaNPK treatments fertilized with post-fermentation products (MPF1, MPF2, GCF1, GCF2) and control $\left[\mathrm{mg} \cdot \mathrm{kg}^{-1}\right]$.

\begin{tabular}{|c|c|c|c|c|c|}
\hline Treatment & MPF1 & MPF2 & GCF1 & GCF2 & Control \\
\hline 0 & $6,07^{\mathrm{a}}$ & $6,85^{\mathrm{b}}$ & $7,06^{\mathrm{b}}$ & $7,04^{\mathrm{b}}$ & $6,69^{\mathrm{b}}$ \\
\hline NPK & 7,91 & 7,82 & 8,20 & 7,74 & 7,08 \\
\hline CaNPK & $6,55^{\mathrm{a}}$ & $7,96^{\mathrm{bc}}$ & $7,88^{\mathrm{bc}}$ & $7,84^{\mathrm{b}}$ & $8,07^{\mathrm{c}}$ \\
\hline
\end{tabular}

$\mathrm{a}, \mathrm{b}, \mathrm{c}=\mathrm{p}<0,05$

Source: own study 
decrease in $\mathrm{Zn}$ compared to the level of the element in the controls. In contrast, soil amendment with NPK fertilizer did not cause significant differences in $\mathrm{Zn}$ recovery in soil compared to that in controls. However, in some cases higher $\mathrm{Zn}$ levels were found than in the 0 and CaNPK. The lowest $\mathrm{Zn}$ content $\left(7.08 \mathrm{mg} \cdot \mathrm{kg}^{-1}\right)$ was noted in the control soil sample (non-fertilised with mineral fertilisers or digestate), while the highest content $\left(8.20 \mathrm{mg} \cdot \mathrm{kg}^{-1}\right)$ was measured in the soil fertilised with the GCF1granulated material.

Lagocka et al. [224] studied the content of zinc in digestates obtained from agri-food products. The main factor determining digestate composition was the substrate used for biogas production. The studies yielded values of from $1.4 \mathrm{mg} \cdot \mathrm{kg}^{-1}$ to $15.1 \mathrm{mg} \cdot \mathrm{kg}^{-1} \mathrm{Zn}$ depending on the charge used.

The content of copper in all the fertilization treatments differed in a statistically significant manner $(\mathrm{p}<0.05)$ (Table 5). In treatment 0 , control treatment (0), the highest values of $\mathrm{Cu}$ were observed in the soil with added granulate from the second digester (GCF2), and in the control soil. NPK fertilisation triggered an increase in the $\mathrm{Cu}$ content in the soils studied, which was particularly marked in the treatment with added GCF2 $\left(2.64 \mathrm{mg} \cdot \mathrm{kg}^{-1}\right)$. In contrast, in the CaNPK treatment, markedly higher concentrations were found in the soils treated with fresh digestate (MPF2 and MPF1), while the lowest values were found in the soils with added granulated materials (GCF1 and GFC2).

An analysis of manganese content in the soils showed a significant increase in the amount of this element $(p<0.05)$ in treatment 0 after the application of the granulated materials GCF1 and GCF2 (Table 6). In the control soil, without added mineral fertilisers or digestate (either fresh or granulated), the content of Mn was only $52.70 \mathrm{mg} \cdot \mathrm{kg}^{-1}$. Higher amounts of this element were found in the treatment NPK with added fresh digestate (on average $70 \mathrm{mg} \mathrm{Mn} \cdot \mathrm{kg}^{-1}$ ). In turn, lime-treatment and fertilisation (CaNPK) led to an increase in the content of manganese in the soil, as evidenced by the amount of $\mathrm{Mn}$ in the control soil (over $\left.75 \mathrm{mg} \cdot \mathrm{kg}^{-1}\right)$. However, the addition of digestate resulted in a statistically significant decrease in the Mn content in the soils treated with MPF1 - by approximately 9\%, GCF $1-7 \%$, and MPF $2-4 \%$.

Table 5. Content of copper $(\mathrm{Cu})$ in 0 , NPK and CaNPK treatments fertilized with post-fermentation products (MPF1, MPF2, GCF1, GCF2) and control $\left[\mathrm{mg} \cdot \mathrm{kg}^{-1}\right]$.

\begin{tabular}{|c|c|c|c|c|c|}
\hline Treatment & MPF1 & MPF2 & GCF1 & GCF2 & Control \\
\hline 0 & $1,58^{\mathrm{ab}}$ & $1,39^{\mathrm{a}}$ & $1,64^{\mathrm{b}}$ & $2,39^{\mathrm{c}}$ & $2,59^{\mathrm{d}}$ \\
\hline NPK & $2,34^{\mathrm{ab}}$ & $2,15^{\mathrm{a}}$ & $2,41^{\mathrm{ab}}$ & $2,64^{\mathrm{b}}$ & $2,32^{\mathrm{a}}$ \\
\hline CaNPK & $2,43^{\mathrm{c}}$ & $2,91^{\mathrm{d}}$ & $1,42^{\mathrm{a}}$ & $1,49^{\mathrm{a}}$ & $1,77^{\mathrm{b}}$ \\
\hline
\end{tabular}

$\mathrm{a}, \mathrm{b}, \mathrm{c}=\mathrm{p}<0,05$

Source: own study
Table 6. Content of manganese (Mn) in 0, NPK and CaNPK treatments fertilized with post-fermentation products (MPF1, MPF2, GCF1, GCF2) and control [mg $\left.\cdot \mathrm{kg}^{-1}\right]$.

\begin{tabular}{|c|c|c|c|c|c|}
\hline Treatment & MPF1 & MPF2 & GCF1 & GCF2 & Control \\
\hline 0 & $56,17^{\text {ab }}$ & $56,21^{\text {ab }}$ & $61,22^{\mathrm{b}}$ & $60,27^{\mathrm{b}}$ & $52,70^{\mathrm{a}}$ \\
\hline NPK & $69,96^{\mathrm{b}}$ & $71,1^{\mathrm{b}}$ & $62,40^{\mathrm{a}}$ & $58,18^{\mathrm{a}}$ & $59,84^{\mathrm{a}}$ \\
\hline CaNPK & $69,21^{\mathrm{a}}$ & $72,94^{\mathrm{c}}$ & $70,68^{\mathrm{b}}$ & $74,86^{\mathrm{d}}$ & $75,86^{\mathrm{d}}$ \\
\hline
\end{tabular}

$\mathrm{a}, \mathrm{b}, \mathrm{c}=\mathrm{p}<0,05$

Source: own study

Digestate treatment in treatment 0 , especially in the form of granulated materials, caused a statistically significant $(p<0.05)$ increase of iron content in the soil (Table 7). In the remaining treatments (NPK and CaNPK), the results obtained were quite varied. In the NPK treatment, statistically significantly the highest Fe content $(\mathrm{p}<0.05)$, amounting to $358.21 \mathrm{mg} \cdot \mathrm{kg}^{-1}$, was found in the soil with added digestate from the second digester (MPF2). In contrast, in the limetreated and fertilised soil (CaNPK), the highest iron content was found in the soil without added digestate $\left(351.20 \mathrm{mg} \cdot \mathrm{kg}^{-1}\right)$.

Borek et al. [35] studied the effect of four digestate materials based on different organic substrates on the content of heavy metals ( $\mathrm{Zn}, \mathrm{Cu}, \mathrm{Fe}, \mathrm{Mn}$ ) in the soil. The authors did not find any significant accumulation of heavy metals after digestate application, so they concluded that the digestate materials could be used as a safe alternative to traditional fertilisers. Similarly, Rajmund and Bożym [36], using sewage sludge and composts produced from it, failed to detect any significant differences in the total iron and manganese content compared to the control group.

The content of nickel in treatment 0 was higher in a statistically significant manner $(\mathrm{p}<0.05)$ in the soils treated with the digestate compared to the control soil (Table 8). In the NPK treatment, statistically the lowest $(p<0.05)$ content of $\mathrm{Ni}$ was detected in the soil treated with the fresh digestate MPF2 $\left(0.17 \mathrm{mg} \cdot \mathrm{kg}^{-1}\right)$. The content of $\mathrm{Ni}$ in the MPF1-treated soil and the control soil was higher than in the soil treated with MPF2 by approximately $35 \%$ and $32 \%$, respectively, and in the soils treated with the granulated materials

Table 7. Content of iron $(\mathrm{Fe})$ in 0 , NPK and CaNPK treatments fertilized with post-fermentation products (MPF1, MPF2, GCF1, GCF2) and control $\left[\mathrm{mg} \cdot \mathrm{kg}^{-1}\right]$.

\begin{tabular}{|c|c|c|c|c|c|}
\hline Treatment & MPF1 & MPF2 & GCF1 & GCF2 & Control \\
\hline 0 & $299,99^{\mathrm{ab}}$ & $301,65^{\mathrm{b}}$ & $304,72^{\mathrm{b}}$ & $304,51^{\mathrm{b}}$ & $295,7^{\mathrm{a}}$ \\
\hline NPK & $302,16^{\mathrm{a}}$ & $358,21^{\mathrm{c}}$ & $312,65^{\mathrm{b}}$ & $307,04^{\mathrm{b}}$ & $308,99^{\mathrm{b}}$ \\
\hline CaNPK & $302,16^{\mathrm{ab}}$ & $307,09^{\mathrm{b}}$ & $290,74^{\mathrm{a}}$ & $308,55^{\mathrm{b}}$ & $351,20^{\mathrm{c}}$ \\
\hline
\end{tabular}

a, b, c $=\mathrm{p}<0,05$

Source: own study 
Table 8. Content nickel (Ni) in 0, NPK and CaNPK treatments fertilized with post-fermentation products (MPF1, MPF2, GCF1, GCF2) and control $\left[\mathrm{mg} \cdot \mathrm{kg}^{-1}\right]$.

\begin{tabular}{|c|c|c|c|c|c|}
\hline Treatment & MPF1 & MPF2 & GCF1 & GCF2 & Control \\
\hline 0 & $0,28^{\mathrm{b}}$ & $0,25^{\mathrm{b}}$ & $0,28^{\mathrm{b}}$ & $0,27^{\mathrm{b}}$ & $0,22^{\mathrm{a}}$ \\
\hline NPK & $0,26^{\mathrm{d}}$ & $0,17^{\mathrm{a}}$ & $0,22^{\mathrm{bc}}$ & $0,21^{\mathrm{b}}$ & $0,25^{\mathrm{cd}}$ \\
\hline CaNPK & $0,54^{\mathrm{c}}$ & $0,57^{\mathrm{c}}$ & $0,49^{\mathrm{ab}}$ & $0,52^{\mathrm{cd}}$ & $0,46^{\mathrm{a}}$ \\
\hline
\end{tabular}

$\mathrm{a}, \mathrm{b}, \mathrm{c}=\mathrm{p}<0,05$

Source: own study

by approximately $23 \%$ and $19 \%$, respectively. Markedly higher amounts of this element were detected in the NPK-fertilised and lime-treated (CaNPK) treatments. Statistically the highest $(\mathrm{p}<0.05)$ content of $\mathrm{Ni}$ was determined in the soil treated with the fresh digestates (MPF2 and MPF1) and granulated material (GCF2). In the control soil, the content of $\mathrm{Ni}$ increased by approximately $52 \%$ and $46 \%$ compared to the treatments 0 and NPK, respectively.

Alongside lead and mercury, cadmium is a heavy metal proven to have the most toxic effect on animals and humans. It has been linked to multiple severe disorders [37, 38]. Therefore, it is very important that digestate-based fertilisation does not lead to high increases in $\mathrm{Cd}$ content in the soil. In treatment 0 (nonfertilised and non-lime-treated), the application of the digestate statistically significantly $(p<0.05)$ contributed to an increase in the content of cadmium by $13-27 \%$, compared to the control soil (Table 9). No statistical differences were found in the NPK and CaNPK treatments. However, mineral fertilisation (NPK) with added digestate, particularly in the granulated form, resulted in a more than two-fold increase in the $\mathrm{Cd}$ content in the studied soils, compared to treatment 0 . In contrast, the amount of cadmium in the CaNPK treatment was radically decreased, ranging from 0.11 to $0.15 \mathrm{mg} \cdot \mathrm{kg}^{-1}$.

An analysis of lead content in the soil showed statistically significant differences $(p<0.05)$ in two treatments: 0 and CaNPK (Table 10). In treatment 0 , non-fertilised with mineral fertilisers, the highest lead content was measured in the soils where the granulated materials (GCF1 and GCF2) were applied,

Table 9. Content of cadmium (Cd) in 0, NPK and CaNPK treatments fertilized with post-fermentation products (MPF1, MPF2, GCF1, GCF2) and control $\left[\mathrm{mg} \cdot \mathrm{kg}^{-1}\right]$.

\begin{tabular}{|c|c|c|c|c|c|}
\hline Treatment & MPF1 & MPF2 & GCF1 & GCF2 & Control \\
\hline 0 & $0,28^{\mathrm{b}}$ & $0,25^{\mathrm{b}}$ & $0,28^{\mathrm{b}}$ & $0,27^{\mathrm{b}}$ & $0,22^{\mathrm{a}}$ \\
\hline NPK & 0,63 & 0,63 & 0,76 & 0,76 & 0,66 \\
\hline CaNPK & 0,14 & 0,15 & 0,11 & 0,12 & 0,13 \\
\hline
\end{tabular}

$\mathrm{a}, \mathrm{b}, \mathrm{c}=\mathrm{p}<0,05$

Source: own study
Table 10. Content of lead $(\mathrm{Pb})$ in 0 , NPK and CaNPK treatments fertilized with post-fermentation products (MPF1, MPF2, GCF1, GCF2) and control $\left[\mathrm{mg} \cdot \mathrm{kg}^{-1}\right]$.

\begin{tabular}{|c|c|c|c|c|c|}
\hline Treatment & MPF1 & MPF2 & GCF1 & GCF2 & Control \\
\hline 0 & $8,31^{\mathrm{ab}}$ & $8,36^{\mathrm{ab}}$ & $9,21^{\mathrm{c}}$ & $8,71^{\mathrm{bc}}$ & $7,83^{\mathrm{a}}$ \\
\hline NPK & 8,93 & 8,67 & 8,66 & 8,32 & 8,88 \\
\hline CaNPK & $8,76^{\mathrm{ab}}$ & $9,05^{\mathrm{b}}$ & $8,32^{\mathrm{a}}$ & $9,01^{\mathrm{b}}$ & $9,70^{\mathrm{c}}$ \\
\hline
\end{tabular}

a, b, c $=p<0,05$

Source: own study

and it was the lowest in the control soil. In contrast, in the CaNPK treatment, the highest amount of $\mathrm{Pb}$ was detected in the control soil, and it was lower in the soil with added fresh digestate and granulated digestate material from the second digester (MPF2 and GCF2). In the soil treated with fresh digestate and granulated digestate material from the first fermenter (MPF1 and GCF1), the amount of this element did not exceed $8.80 \mathrm{mg} \cdot \mathrm{kg}^{-1}$.

Other studies [3] evaluating digestate-based compost did not show that the heavy metal content in soils exceeded maximum permitted limits. A statistically significantly lower content of assimilable forms of metals $(\mathrm{Ni}, \mathrm{Pb}$ and $\mathrm{Fe}$ ) was found in the fertilised (NPK) and lime-treated (CaNPK) treatments, with added compost (except for compost obtained in the process of methane fermentation of maize silage combined with distillers' solubles at a dose equivalent to $85 \mathrm{~kg} \mathrm{~N} / \mathrm{ha}$ ), and $\mathrm{Zn}$ and $\mathrm{Ni}$ in the soil with no mineral fertilisation. In the NPK treatment, there was a significant decrease in the content of the majority of studied metals, with the exception of $\mathrm{Cu}$.

\section{Conclusions}

The experiments performed in the study showed that the maximum permitted limits set out in the Regulation of the Minister of the Environment of 1 September 2016 on the method of conducting assessment of soil surface contamination were not exceeded in any of the treatments. The use of the digestate as a fertiliser brings considerable benefits in agricultural production, and has the potential to reduce the harmful effects of mineral fertilisation. Since methane fermentation products did not result in the accumulation of metals in the soil, the digestate - both fresh and processed into granulated material can be safely used for soil fertilisation. In many cases, it had a statistically significant effect on reducing their soil content compared to the control sample. Consequently, the study found that the application of the digestate did not contaminate the soil environment and the plant world with heavy metals, and hence contributed to the maintenance of human and animal health. 


\section{Conflict of Interest}

The authors declare no conflict of interest.

\section{References}

1. ASKRI A., LAVILle P., TRÉMIER A., HOUOT S. Influence of origin and post-treatment on greenhouse gas emissions after anaerobic digestate application to soil. Waste Biomass Valorization, 7 (2), 293, http://dx.doi. org/10.1007/s12649-015-9452-6, (accessed on 4.11.2019), 2016.

2. HAGOS K., ZONG J., LI D., LIU C., LU X. Anaerobic co-digestion process for biogas production: Progress, challenges and perspectives. Renewable and Sustainable Energy Reviews, 76, 1485-, 2017.

3. PIĄTEK M., BARTKOWIAK, A. Assessment of selected physicochemical properties of soil fertilized with digestate. Water-Environment-Rural Areas, Tom 19 (1), 55, 2019b [In Polish].

4. SADY W., SMOLEŃ S. Influence of soil-fertilizing factors on the accumulation of heavy metals in plants. Effectiveness of using fertilizers in horticultural crops. Agricultural University Publisher August Cieszkowski in Poznan, Poznan, 269, 2004 [In Polish].

5. SOMMER, S. G., SCHJOERRING, J. K., DENMEAD, O. T. Ammonia emission from mineral fertilizers and fertilized crops. Advances in agronomy, 82 (557622), 557, 2004.

6. BODAK E., DOBRZAŃSKI Z. (Ed.) Ecotoxicological problems in animal husbandry in heavy metal contamination areas. Ed. Copper Cup Research and Design Center in Wrocław, Wrocław-Rudna. 132, 1997 [In Polish].

7. CHEN L., ZHOU S., YAXING S., WANG CH., Li B., Li Y., Wu S. Heavy metals in food crops, soil, and water in the Lihe River Watershed of the Taihu Region and their potential health risks when ingested. Science of the Total Environment, 615, 141, 2018.

8. DOBRZAŃSKI Z., KOŁACZ R., GÓRECKA H., CHOJNACKA K., BARTKOWIAK A. The content of microelements and trace elements in raw milk from cows in the Silesian-Region. Polish Journal of Environmental Studies, 14 (5), 685, 2005.

9. OCIEPA-KUBICKA A., OCIEPA E., Toxic effects of heavy metals on plants, animals and people. Engineering and Environmental Protection, 15 (2), 169, 2012 [In Polish].

10. REGULATION OF THE MINISTER OF THE ENVIRONMENT of 1 September 2016 on the manner of conducting an assessment of ground surface pollution (Dz.U. 2016, poz. 1395) [In Polish].

11. ALLOWAY B.J. Soil factors associated with zinc deficiency in crops and humans Environmental Geochemistry and Health, 31 (5), 537, 2009.

12. CLEMENS S. Toxic metal accumulation, responses to exposure and mechanisms of tolerance in plants. Biochimie, 88 (11), 1707, 2006.

13. KABATA-PENDIAS A., PENDIAS H. Trace elements in soils and plants. CRC Press Boca Raton London New York Washington, D.C. International Standard Book Number 0-8493-1575-1, Library of Congress Card Number 00-057964, Printed in the United States of America, 403 2001.

14. KAVAMURA V.N., ESPOSITO E. Biotechnological strategies applied to the decontamination of soils polluted with heavy metals. Biotechnology Advances, 28 (1), 61, 2010.

15. KOVACS H., SZEMMELVEISZ K. Disposal options for polluted plants grown on heavy metal contaminated brownfield lands-a review. Chemosphere, 166, 8, 2017.

16. WIECZOREK J., BARAN A. Zinc content in various elements of the environment in the zone of potential impact of galvanizing plants. Proceedings of ECOpole, $\mathbf{6}$ (1), 2012 [In Polish].

17. GÓRKA A., KOGUT A., KRZYSTYNIAK A. Content of selected heavy metals - lead and cadmium in soils and their toxic effect on plant development. Analit, 3, 32, 2017 [In Polish].

18. OCIEPA E., PACHURA P., OCIEPA-KUBICKA A., Impact of unconventional fertilization on migration of heavy metals in the soil-plant system. Engineering and Environmental Protection, 17 (2), 325, 2014 [In Polish].

19. TCHOUNWOU P.B., YEDJOU C.G., PATLOLLA A.K., SUTTON D.J. Heavy metal toxicity and the environment. In Molecular, clinical and environmental toxicology. Springer, Basel, 133, 2012.

20. KONCEWICZ-BARAN M., GONDEK K. The content of trace elements in agricultural soils. Infrastructure and Ecology of Rural Areas, Branch in Krakow, PAN, 14, 65, 2010 [In Polish].

21. ALBURQUERQUE J. A., DE LA FUENTE C., FERRERCOSTA A., CARRASCO L., CEGARRA J., ABAD M., BERNAL M. P. Assessment of the fertilizer potential of digestates from farm and agroindustrial residues. Biomass and bioenergy, 40, 181, 2012.

22. GONDEK K. Accumulation of heavy metals in oats fertilized with composts. Acta Agrophysica, 10 (1), 89, 2007 [In Polish].

23. KOWALCZYK-JUŚKO A., SZYMAŃSKA M. Digestate with fertilizer for agriculture FDPA. Www. ksow.pl/ uploads/tx_library/files/Poferment_nawozem dla_rolnictwa_01.pdf. (accessed on 1.03.2017), $201 \overline{5}$ [In Polish].

24. ŁAGOCKA A., KAMIŃSKI M., CHOLEWIŃSKI M., POSPOLITA W. Ecological benefits from the use of digestate from agricultural biogas plants as organic fertilizer. Problems of Biological Sciences, KOSMOS Tom 65, 4 (313), 601, 2016 [In Polish].

25. MAKARA A., KOWALSKI Z., FELA K. Utilization of digestate in the aspect of ecological safety. Scientific Works of the Academy Jan Długosz in Częstochowa Technology, IT, Security Engineering V, 177, http://dx.doi. org/10.16926/tiib.2017.05.15 (accessed on 4.11.2019), 2017 [In Polish].

26. OCIEPA E., OCIEPA-KUBICKA A., OKONIEWSKA E., LACH J. Immobilization of zinc and cadmium in soils as a result of the use of waste substrates. Annual Set the Environment Protection, 15, 1772, 2013 [In Polish].

27. PIĄTEK M., BARTKOWIAK A. Analysis of heavy metal content in soil fertilized with compost from digestate. In Improving technology in animal production and renewable energy, taking into account the requirements of sustainable development, Ed. W. Romaniuk, H. Jankowska-Huflejt. Ed. ITP, Falenty-Warsaw, 222, 2019a [In Polish].

28. SZYMAŃSKA M., NOWACZEWSKA D., ŚWIERŻEWSKA E., WRZOSEK-JAKUBOWSKA J., GWOREK B. An attempt to assess the physicochemical properties of soils fertilized with fresh and treated digestate from biogas. Chemical Industry, 95 (3), 572, 2016 [In Polish]. 
29. WAGNER A.O., JANETSCHEK J., ILLMER P., Using digestate compost as a substrate for anaerobic digestion. Chem. Eng. Technol., 41 (4), 1, 2018.

30. WASTE ACT of December 14, 2012 (Dz. U. z 2013, poz.21).

31. PILARSKA A., WOLNA-MARUWKA A., PIECHOTA T., PILARSKI K., SZYMAŃSKA M., WOLICKA D. Preliminary research on digestate pulp from a biogas plant and its composts as potential organic fertilizers. Science Nature Technologies, 9, 2, https://www.npt.uppoznan.net/pub/art_9_19.pdf, (accessed on 2.11.2019), 2015 [In Polish].

32. GARCÍA-MAROTO I., MUÑOZ-LEIVA F., REY-PINO J.M. Qualitative insights into the commercialization of wood pellets: The case of Andalusia, Spain. Biomass and Bioenergy, 64, 245, 2014.

33. KATAKI S., HAZARIKA S., AND BARUAH D.C. Assessment of by-products of bioenergy systems (anaerobic digestion and gasification) as potential crop nutrient. Waste management, 59, 102, 2017.

34. KUPPERA T., BÜRGEB D., BACHMANNB H.J., GÜSEWELLA S., MAYERB J. Heavy metals in source- separated compost and digestates. Waste Management, 34, 867, 2014.

35. BOREK K., BARWICKI J., MAZUR K., MAJCHRZAK M., WARDAL W.J. Evaluation of the impact of digestate formed during biogas production on the content of heavy metals in soil. Scientific Quarterly Journal Agricultural Engineering, 2 (154), 15, 2015.

36. RAJMUND A., BOŻYM M. Changes in iron and manganese content in light soil fertilized with sewage sludge and composts during a 6-year lysimeter experiment. Water-Environment-Rural areas. T. 17, 1 (57), 101, 2017 [In Polish].

37. BOLAN N., KUNHIKRISHNAN A., THANGARAJAN R., KUMPIENE J., PARK J., MAKINO T., KIRKHAM M.B., CHECKEL K. Remediation of heavy metal (loid) s contaminated soils - to mobilize or to immobilize? Journal of Hazardous Materials, 266, 14, 2014.

38. KIRKHAM M. B. Cadmium in plants on polluted soils: effects of soil factors, hyperaccumulation, and amendments. Geoderma, 137 (1-2), 19, 2006. 